RESEARCH NOTE

\title{
Common bean seed vigor affecting crop grain yield ${ }^{1}$
}

\author{
Vitor Henrique Vaz Mondo ${ }^{2 *}$, Adriano Stephan Nascente ${ }^{2}$, \\ Manoel Oliveira Cardoso Neto ${ }^{3}$
}

\begin{abstract}
Among the factors that affect seedling emergence and crop establishment are seed germination and vigor, which has an important influence on the establishment of the initial plant population and development, and may affect crop yield. Based on this background the objective of this research work was to evaluate the effects of seed vigor of common bean seed lots and its effects on crop grain yield. The treatments consisted of six seed lots of common bean, which were composed by different combinations of high and low vigor seeds. Seed lots were assessed by germination and vigor tests (first count of germination, electrical conductivity and accelerated aging). A field experiment was conducted in a randomized block design, with plots of six lines of five meters and were evaluated for grain yield at harvest. It was concluded that seed vigor affects common bean grain yield; the use of low vigor seeds results in grain yield reductions of up to $20 \%$.
\end{abstract}

Index term: Phaseolus vulgaris L., dry bean, seed quality, seed analysis, crop performance.

\section{Vigor de sementes de feijão-comum afetando a produtividade de grãos da cultura}

\begin{abstract}
RESUMO - Entre os fatores que afetam a emergência das plântulas e o estabelecimento da cultura estão a germinação e o vigor das sementes, que têm influência importante sobre o estabelecimento da população de plantas e o seu desenvolvimento inicial, podendo afetar a produtividade da cultura. Neste contexto, o objetivo deste trabalho foi avaliar os efeitos do vigor de sementes de lotes de sementes de feijão-comum sobre a produtividade da cultura. Os tratamentos consistiram de seis lotes de sementes de feijão-comum, que foram compostos por diferentes combinações de sementes de alto e baixo vigor. Os lotes de sementes foram avaliados por meio de testes de germinação e de vigor (primeira contagem de germinação, condutividade elétrica e envelhecimento acelerado). Um experimento de campo foi conduzido em delineamento em blocos casualizados, com parcelas de seis linhas de cinco metros e, foram avaliados pela produtividade de grãos na colheita. Pelos dados obtidos concluiu-se que o vigor das sementes afeta a produtividade da cultura do feijão-comum; o uso de sementes com baixo vigor resulta em perdas de produtividade de até $20 \%$.
\end{abstract}

Termos para indexação: Phaseolus vulgaris L., feijão seco, qualidade de sementes, análise de sementes, desempenho da cultura.

\section{Introduction}

Crop management, such as a uniform seed bed and constant planting depth, is designed to encourage uniform plant establishment, and should maximize the yield of cultivated crops. Non-uniform spatial distribution of plants along the sowing row and uneven seedling emergence result in plant-toplant variability among adult plants and can be responsible for reducing crop production (Liu et al., 2004a, 2004b; Andrade

${ }^{1}$ Submitted on $07 / 19 / 2016$. Accepted for publication on 11/08/2016. ${ }^{2}$ Embrapa Arroz e Feijão, Caixa Postal 179, 75375-000 - Santo Antônio de Goiás, GO, Brasil. and Abbate, 2005; Tollenaar et al., 2006). Among the factors that affect seedling emergence and crop establishment are seed germination and vigor, which, according to Hampton (2002), has an important influence on the establishment of the initial plant population and development, and affects crop yield.

Differences in the emergence rate affect the development of the crop canopy, and the seedlings that emerge first shade those that emerge later (Pommel et al., 2002). The competition resultant from uneven seedling emergence and 
plant development could lead to dominated plants by earlier emerging neighboring plants (Merotto-Júnior et al., 1999). Differences in initial crop growth related to seed vigor are described in the literature for rice (Hofs et al., 2004; Melo et al., 2006; Mielerzski et al., 2008), black oats (Schuch et al., 2000), maize (Dias et al., 2010, Mondo et al., 2012, Mondo et al., 2013a, Mondo et al., 2013b) and soybean (Egli, 1993; Vanzolini and Carvalho, 2002; Kolchinski et al., 2005; Kolchinski et al., 2006; Schuch et al., 2009; Dias et al., 2011). In addition, seed vigor has impacts on crop cultivation cycle, with plants from lower vigor seeds presenting a delayed development compared to higher vigor seeds; however, such differences tend to disappear during the reproductive phase (Egli, 1993; Mondo et al., 2015). Egli (1993) reported that variation in time of emergence, which created differences in plant size in the community, provided no effect on grain yield per unit area in soybean. These effects are characteristics of heterogeneous seed lots in term of seed vigor (Mondo et al., 2012, Mondo et al., 2013a, Mondo et al., 2013b).

In another perspective, crop yield is correlated with efficient resource uptake, including water, nutrients and solar radiation, and a faster initial growth will probably result in a better competitive ability and higher crop grain yields. Dias et al. (2010), working with maize, found that seed vigor is directly related to initial crop growth and that affects plant competitive ability with regard to weeds with inferior growth rates. Furthermore, seed vigor has direct effects on maize yield during maximized competition for the uptake of resources. For soybean, plants which developed from seeds with high and intermediate vigor showed the best results for competition against weeds, reducing weed dry mass accumulation, and plants which developed from high vigor seeds give the best results for grain yield for both weeded and unweeded treatments (Dias et al,. 2011).

Grain yield in common bean crop is influenced by many factors, such as disease, pests, weeds, mineral nutrition, environmental conditions, and seed density. The use of improved cultural practices has enabled significant increases in grain yield of this crop (Didonet, 2005). Among those practices, plant population and row spacing are included, as it is directly related to the grain yield components, as number of pods plant per plant, number of grains per pod and mass of 100 seeds (Azevedo et al., 2008). In this scenario, the use of high quality seeds is fundamental to obtain a uniform plant distribution and final population as a mean to obtain high grain yield and expressing the maximum genetic potential.

Based on this background the objective of this research work was to evaluate the effects of seed vigor of common bean seed lots and its effects on crop grain yield.

\section{Material and Methods}

The treatments consisted of six seed lots of common bean (Phaseolus vulgaris L.), which were composed by different combinations of high and low vigor seeds as follows: Lot 1 was composed by $100 \%$ of high vigor seeds (HVS); Lot 2 by $80 \%$ of HVS and $20 \%$ of low vigor seeds (LVS); Lot 3 by $60 \%$ of HVS and $40 \%$ of LVS; Lot 4 by $40 \%$ of HVS and $60 \%$ of LVS; Lot 5 by $20 \%$ of HVS and $80 \%$ of LVS; and Lot 6 by $100 \%$ of LVS. All treatments were originated from only one seed lot of 'Pérola' variety, which was previously divided in two samples and one sample was submitted to an accelerated aging process $\left(41 \pm 1{ }^{\circ} \mathrm{C}\right.$ for $72 \mathrm{~h}$ ), resulting in one lot with HVS and another with LVS.

Seed lot assessment was conducted by the following tests at Embrapa Rice and Bean's seed quality laboratory:

Germination $(G)$ : carried out with four replicates of 50 seeds per lot in rolled paper towels. Seeds were uniformly distributed on two germination paper towels moistened with water to 2.5 times the dry paper weight and covered with another towel. The rolls were vertically placed in a dark germination chamber at 25 $\pm 1^{\circ} \mathrm{C}$. The percentage of normal seedlings was recorded on the fifth, for first count of germination evaluation ( $F C G$ ), and ninth day after sowing (Brasil, 2009).

Accelerated aging $(A A)$ : performed with four replicates of 50 seeds per lot. The seeds were placed upon a screen inside transparent plastic boxes $(11.5 \times 11.5 \times 3.5 \mathrm{~cm})$ and suspended over $40 \mathrm{~mL}$ of water. The boxes were placed in a germination chamber and maintained at $41{ }^{\circ} \mathrm{C} \pm 1{ }^{\circ} \mathrm{C}$ for $72 \mathrm{~h}$ (Kappes et al., 2012). After the aging period, seeds were submitted to germination test, as described previously, and the normal seedling percentage was determined on the fifth day after sowing. The same aging process was used for preparing LVS lots.

Electrical conductivity (EC): determined using four replicates of 50 seeds each per seed lot. The samples had been previously weighed $(0.1 \mathrm{~g}$ accuracy) and were placed in plastic containers $(200 \mathrm{~mL})$ with $75 \mathrm{~mL}$ of deionized water and kept at $25{ }^{\circ} \mathrm{C}$ for $24 \mathrm{~h}$ in a germination chamber. The electrical conductivity of the solution was determined using a Digimed DM-20 conductivity meter $\left(\mu \mathrm{S} \mathrm{cm}{ }^{-1} \cdot \mathrm{g}^{-1}\right)$, as described by Kappes et al. (2012).

The field experiment was conducted at the "Fazenda Capivara," Embrapa Rice and Beans, located in Santo Antônio de Goiás, GO, at $16^{\circ} 28^{\prime} 00^{\prime \prime} \mathrm{S}$ and $49^{\circ} 17^{\prime} 00$ “ W, and 823 $\mathrm{m}$ of altitude. The climate is tropical savanna, considered Aw according to the Köppen classification (Kottek et al., 2006). There are two well-defined seasons, normally dry from May to September (autumn /winter) and rainy from October to April (spring /summer), the average annual rainfall is between 
1500-1700 mm. The average annual temperature is $22.7^{\circ} \mathrm{C}$, ranging annually from $14.2{ }^{\circ} \mathrm{C}$ to $34.8^{\circ} \mathrm{C}$ (Silva et al., 2010).

The soil is classified as a clay loam (kaolinitic, thermic Typic Haplorthox) acidic soil (Embrapa, 2006). Before the deployment of the field trial, in May 2014, chemical analyzes were performed at a depth of $0-0.05,0.05-0.10$ and $0.10-0.20 \mathrm{~m}$ to characterize the experimental area (Table 1). The chemical analyzes were performed according to the methodology proposed by Claessen (1997). The soil $\mathrm{pH}$ was determined in a $0.01 \mathrm{~mol} . \mathrm{L}^{-1} \mathrm{CaCl}_{2}$ suspension (1:2.5 soil/solution). Exchangeable $\mathrm{Ca}, \mathrm{Mg}$, and $\mathrm{Al}$ were extracted with neutral 1 mol. $\mathrm{L}^{-1} \mathrm{KCl}$ in a 1:10 soil/solution ratio and determined by titration with a $0.025 \mathrm{~mol} . \mathrm{L}^{-1} \mathrm{NaOH}$ solution. Phosphorus and exchangeable $\mathrm{K}$ were extracted with a Mehlich 1 extracting solution $\left(0.05 \mathrm{M} \mathrm{HCl}\right.$ in $\left.0.0125 \mathrm{M} \mathrm{H}_{2} \mathrm{SO}_{4}\right)$. The extracts were calorimetrically analyzed for $\mathrm{P}$, and flame photometry was used to analyze $\mathrm{K}$. The base saturation values were calculated using the results of for exchangeable bases and total acidity at $\mathrm{pH} 7.0(\mathrm{H}+\mathrm{Al})$. Micronutrients were determined in Mehlich 1 extract by atomic absorption, and organic matter was determined by the method of Walkley and Black.

Table 1. Chemical soil attributes from the experimental area before the beginning of the trials. Santo Antônio de Goiás, Goiás, Brazil, growing season 2014.

\begin{tabular}{|c|c|c|c|c|c|c|}
\hline Layer & $\mathrm{pH}$ & $\mathrm{Ca}$ & $\mathrm{Mg}$ & $\mathrm{Al}$ & $\mathrm{H}+\mathrm{Al}$ & SOM§ \\
\hline $\mathrm{cm}$ & in $\mathrm{H}_{2} \mathrm{O}$ & \multicolumn{4}{|c|}{$\mathrm{mmol}_{\mathrm{c}} \cdot \mathrm{kg}^{-1}$} & g. $\mathrm{kg}^{-1}$ \\
\hline $0-5$ & 6.2 & 18 & 14 & 0 & 38 & 28.0 \\
\hline 5 a 10 & 5.9 & 17 & 10 & 0 & 26 & 24.8 \\
\hline 10 a 20 & 5.7 & 11 & 7 & 1 & 23 & 27.8 \\
\hline Layer & $\mathrm{P}$ & $\mathrm{K}$ & $\mathrm{Cu}$ & $\mathrm{Zn}$ & $\mathrm{Fe}$ & $\mathrm{Mn}$ \\
\hline $\mathrm{cm}$ & \multicolumn{6}{|c|}{ Mg.kg ${ }^{-1}$} \\
\hline $0-5$ & 12.6 & 265 & 0.9 & 10.7 & 17.7 & 9.8 \\
\hline 5 a 10 & 18.7 & 125 & 1.5 & 8.1 & 29.5 & 8.0 \\
\hline 10 a 20 & 12.4 & 87 & 1.6 & 4.9 & 29.6 & 7.0 \\
\hline
\end{tabular}

$\S \mathrm{SOM}$ - soil organic matter.

The experimental design was in a randomized block scheme and treatments consisted of the six seed lots of common bean with four replications. Each plot consisted of six five-meters-long rows, with a useful area of four central rows, disregarding $0.5 \mathrm{~m}$ from the ends of each row. A space of one meter among plots was used.

The experimental area has been cultivated in crop-livestock and no-tillage system (NTS), with crop rotation program including soybean, maize and brachiaria (summer), and common bean (winter). The previous crop in the area was maize. The field trials were fertilized according to soil analysis, complemented by a topdressing fertilization in all plots with $60 . \mathrm{kg} \mathrm{ha}^{-1}$ of $\mathrm{N}$ as urea when the treatment one (Lot 1) reached the V4 vegetative stage (four trifoliate leaves). Other cultural practices were performed according to the recommendations for the crop to keep the area free of weeds, diseases and insects (Santos et al., 2006). The sowing was performed manually on May $20^{\text {th }}, 2014$ at $0.50 \mathrm{~m}$ row spacing and a population of 240,000 plants.ha ${ }^{-1}$. A sprinkler irrigation system was used as needed. In the management of water it was used three crop coefficients $(\mathrm{Kc})$, divided into four periods between emergence and harvest. In the vegetative stage the value of 0.4 was used. For the reproductive phase two values of $\mathrm{Kc}$ were used, the initial 0.7 to 1.0 , and in the final phase of maturation these values were reversed, ie initial 1.0 and final 0.7 . Thus, control of irrigation considering the depth of root system exploitation of $0.2 \mathrm{~m}$ was initiated with the available water capacity (AWC) at its maximum, subtracting, successively, the value of crop evapotranspiration until the total water reached the minimum limit of $40 \%$ of AWC (Doorenbos and Pruitt, 1976).

Seedling emergence occurred at nine days after sowing for treatment one (Lot 1) and three days later for the treatment six (Lot 6). After emergence, the plots were thinned manually to reach a homogeneous plant stand of 220.000 plants.ha ${ }^{-1}$, eliminating the germination variation and assuring just the vigor differences among treatments. The usable area of the plots was harvested on August $21^{\text {st }}$, also manually, followed by mechanized thresher. The harvested common bean grains were weighed, transformed to $\mathrm{kg} \cdot \mathrm{ha}^{-1}$ and yield expressed on a $13 \%$ basis of water content. Water content (WC) was determined by the oven method, drying two seed subsamples of $20 \mathrm{~g}$ from each seed lot at $105^{\circ} \mathrm{C} \pm 3{ }^{\circ} \mathrm{C}$ for $24 \mathrm{~h}$, followed by weighing (Brasil, 2009), with results expressed as percentage.

All data was subjected to analysis of variance. Seed quality assessment was conducted in a complete randomized design and the field trial in a randomized block design. If there were significant differences, for seed quality data, means were compared by Scott-Knot test at $\mathrm{p} \leq 0.05$ complemented 
by regression analysis, and for grain yield, the results were analyzed by regression analysis.

\section{Results and Discussion}

The results of seed vigor potential are presented in Figure 1. In the way the seed lots were produced, using seed mixtures, the Seed Lots 1 to 4 kept the same level of germination results (Figure 1A), from $86 \%$ to $79 \%$, however, Seed Lots 5 and 6 were inferior of this group, reaching a band from $71 \%$ to $69 \%$ germination. This is an important data to be analyzed, because differences in germination could directly affect the final plant population of any crop and consequently affect the grain yield.
Therefore, for the purpose of this experiment it had not influence, considering that the plots were thinned manually and reached a homogeneous plant population of 220.000 plants.ha ${ }^{-1}$.

The seed vigor was evaluated by the physiological tests of first count of germination (Figure 1B), electrical conductivity (Figure 1C) and accelerated aging (Figure 1D). The results from first count of germination were very similar to the germination results, with Seed Lots 1 to 4 as the most vigorous ones. The other vigor tests could at least divide the seed lots in two groups, Seed Lots 1 to 3 with high vigor and Seed Lots 4 to 6 with low vigor. Those differences were expected considering the way the treatments were composed, using different combinations of high and low vigor seeds.
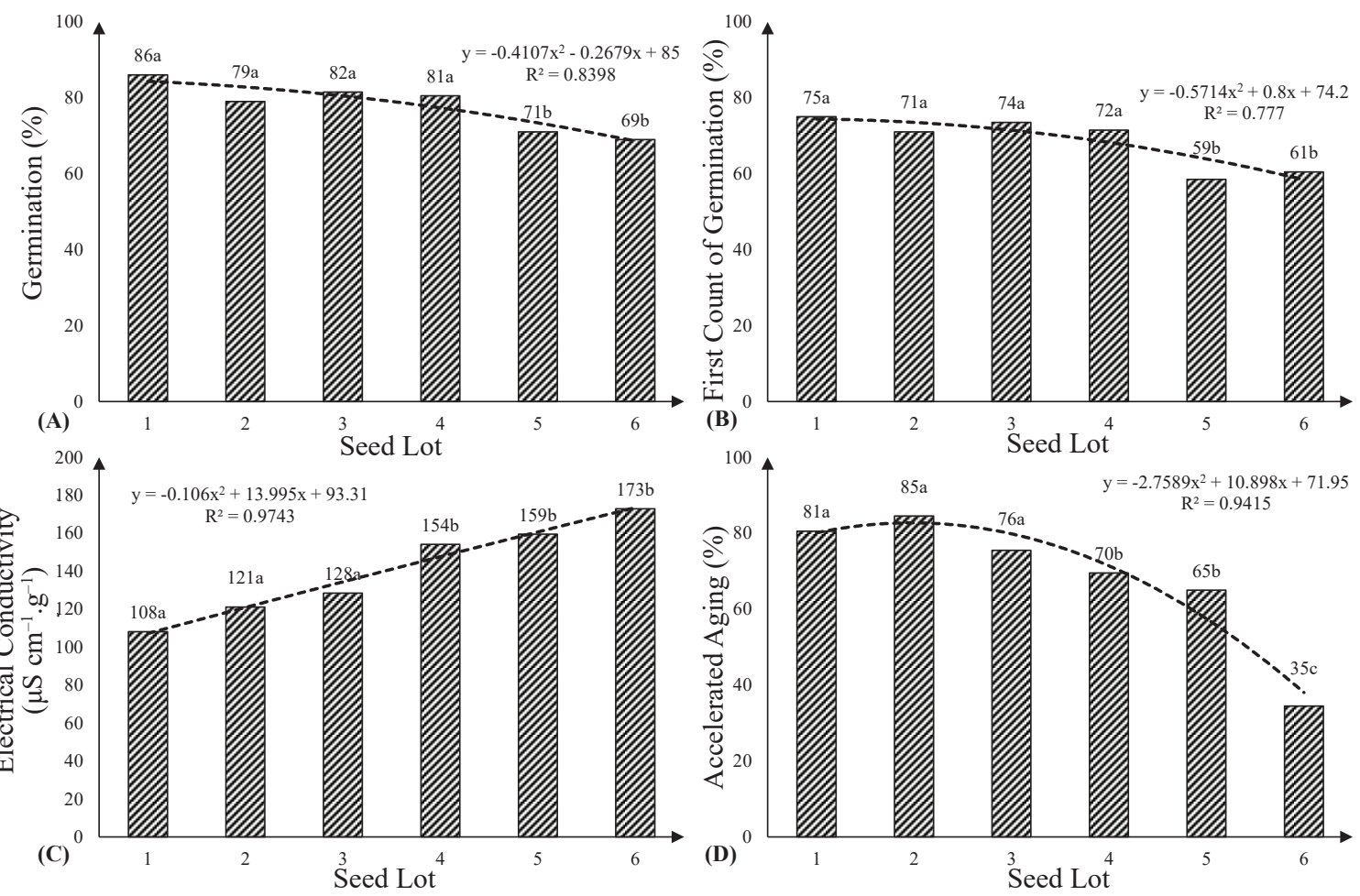

Figure 1. Physiological potential of common bean seed, "Perola" variety, according to the seed vigor level: Seed Lot 1 (highest level); Seed Lot 6 (lowest level): (A) Germination (\%); (B) First Count of Germination (\%); (C) Electrical Conductivity $\left(\mu \mathrm{S} \mathrm{cm}^{-1} \cdot \mathrm{g}^{-1}\right)$; (D) Accelerated Aging (\%).

The main result of this research work is related to the grain yield obtained in each treatment. Those data area presented in Figure 2. As expected different results among the imposed treatments were found even between seed lots belonging to the same seed vigor level, as illustrated in Figure 1. There were two different levels of grain yield, one including Seed Lots 1 to 3 , higher vigor seed lots, and one including seed lots 4 to 6 , lower vigor seed lots. The differences between the higher result, mean grain yield of 1.903,2 kg.ha-1, to the lower result, mean grain yield of $1.571,8 \mathrm{~kg} \cdot \mathrm{ha}^{-1}$, represents yield losses of around $20 \%$ from one vigor group to another. In a more detailed analysis, even inside the high seed vigor lots group, it was possible to see tendencies of grain yield losses. Those differences were between $5 \%$ and $10 \%$, and shows that slight differences, on seed vigor could affect crop success. Similar results were found by Hofs et al. (2004), Melo et al. (2006) and Mielerzski et al. (2008) for rice, Dias et al. (2010), Mondo et al. (2012), Mondo et al. (2013a) and Mondo 
et al. (2013b) for maize, and Vanzolini and Carvalho (2002), Kolchinski et al. (2005), Kolchinski et al. (2006), Schuch et al. (2009) and Dias et al. (2011) for soybean.

Another interesting result, important to quality control programs and seed quality evaluation, is that the germination and first count of germination were not detailed enough to segregate the seed lots by vigor level and reflect the grain yield potential. Complementary, seed vigor tests, as electrical conductivity and accelerated aging, were crucial and should be included in quality control programs of common bean seeds.

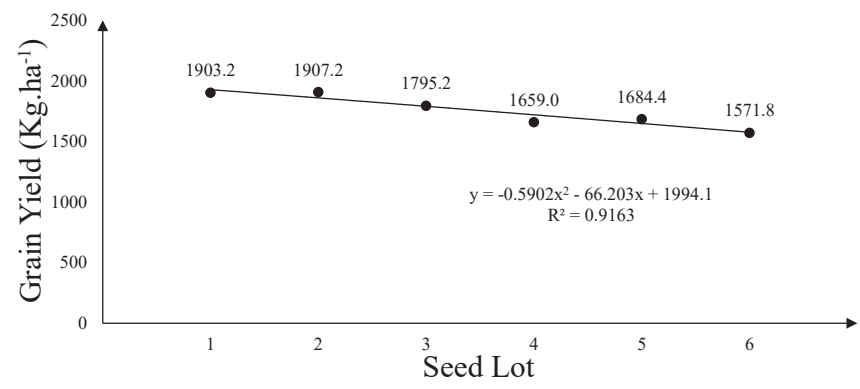

Figure 2. Grain yield of common bean, "Perola" variety, from seed lots differing in seed vigor. Seed Lot 1 (highest level); Seed Lot 6 (lowest level).

\section{Conclusions}

Seed vigor affects common bean grain yield; the use of low vigor seeds results in grain yield reductions of up to $20 \%$.

\section{References}

ANDRADE, F.H.; ABBATE, P.E. Response of maize and soybean to variability in stand uniformity. Agronomy Journal, v.97, n.4, p.1263-1269, 2005. https://dl.sciencesocieties.org/publications/aj/abstracts/97/4/1263

AZEVEDO, J.A.; SILVA, E.M.; RODRIGUES, G.C.; GOMES, A.C. Produtividade do feijão de inverno influenciada por irrigação, densidade de plantio e adubação em solo de Cerrado. Planaltina, Embrapa Cerrados, 2008. 3p. http://www.infoteca.cnptia.embrapa.br/handle/doc/571897

BRASIL. Ministério da Agricultura, Pecuária e Abastecimento. Regras para análise de sementes. Ministério da Agricultura, Pecuária e Abastecimento. Secretaria de Defesa Agropecuária. Brasília: MAPA/ACS, 2009. 395p. http:// www.agricultura.gov.br/arq_editor/file/2946_regras_analise_sementes.pdf

CLAESSEN, M.E.C. Manual de métodos de análise de solo. $2^{\mathrm{a}}$ ed. Rio de Janeiro, EMBRAPA-CNPS. (EMBRAPA-CNPS. Documentos, 1). 1997. 212p. https://www.agencia.cnptia.embrapa.br/Repositorio/ Manual+de+Metodos_000fzvhotqk02wx5ok0q43a0ram31wtr.pdf

DIAS, M.A.N.; MONDO, V.H.V.; CICERO, S.M. Maize seed vigor and weed competition. Journal of Seed Science, v.32, n.2, p.93-101, 2010. http://www. scielo.br/scielo.php?script=sci arttext\&pid=S0101-31222010000200011
DIAS, M.A.N.; PINTO, T.L.F.; MONDO, V.H.V.; CICERO, S.M.; PEDRINI, L.G. Direct effects of soybean seed vigor on weed competition. Journal of Seed Science, v.33, n.2, p.346-351, 2011. http://www.scielo.br/ scielo.php?script $=$ sci_arttext\&pid=S0101-31222011000200017

DIDONET, A.D. Ecofisiologia e rendimento potencial do feijoeiro. In: DEL PELOSO, M.J.; MELO, L.C. (Eds.) Potencial de rendimento da cultura do feijoeiro comum. Santo Antônio de Goiás, Embrapa Arroz e Feijão, 2005, p.9-37.

DOORENBOS, J.; PRUITT, W.O. Crop and water requirements. Rome, FAO. (FAO Irrigation and Drainage Paper n. 24). 1976. 179p.

EGLI, D.B. Relationship of uniformity of soybean seedling emergence to yield. Journal of Seed Technology, v.17, n.1, p. 22-28, 1993.

EMBRAPA. Centro Nacional de Pesquisa de Solos. Sistema Brasileiro de Classificação de Solos. 2 ed. Rio de Janeiro, Embrapa Solos. 2006. 306p.

HAMPTON, J.G. What is seed quality? Seed Science and Technology, v.30, p.1-10. 2002. http://cat.inist.fr/?aModele=afficheN\&cpsidt $=13659037$

HOFS, A.; SCHUCH, L.O.B.; PESKE, S.T.; BARROS, A.C.S.A. Emergência e crescimento de plântulas de arroz em resposta à qualidade fisiológica de sementes. Journal of Seed Science, v.26, n.1, p.92-97, 2004. http://www. scielo.br/pdf/\%0D/rbs/v26n1/a14v26n1.pdf

KAPPES, C.; ARF, O.; FERREIRA, J.P.; PORTUGAL, J.R.; ALCALDE, A.M.; ARF, M.V.; VILELA, R.G. Physiological quality of seeds and growth of bean seedlings in relation to pre-harvest paraquat applications. Pesquisa Agropecuária Tropical, v.42, n.1, p.9-18. 2012. http://www.scielo.br/scielo. php?script=sci_arttext\&pid=S1983-40632012000100002

KOLCHINSKI, E.M.; SCHUCH, L.O.B.; PESKE, S.T. Seeds vigor and intra-specific compettion in soybean. Ciência Rural, v.35, n.6, p.1248-1256, 2005. http://www.scielo.br/scielo.php? script=sci arttext\&pid $=$ S010384782005000600004\&lng=en\&nrm $=$ iso

KOLCHINSKI, E.M.; SCHUCH, L.O.B.; PESKE, S.T. Early growth of soybean plants in relation to seeds vigor. Revista Brasileira de Agrociencia, v.12, n.2, p.163-166, 2006. http://www.ufpel.tche.br/faem/agrociencia/ v12n2/artigo07.htm

KOTTEK, M.; GRIESER, J.; BECK, C.; RUDOLF, B.; RUBEL, F. World map of the Köppen-Geiger climate classification updated. Meteorologische Zeitschrift, v.15, n.3, p.259-263, 2006.

LIU, W.; TOLLENAAR, M.; STEWART, G.; DEEN, W. Within-row plant spacing variability does not affect maize yield. Agronomy Journal, v.96, n.1, p.275-280, 2004a. https://dl.sciencesocieties.org/publications/aj/ abstracts/96/1/275

LIU, W.; TOLLENAAR, M.; STEWART, G.; DEEN, W. Response of maize grain yield to spatial and temporal variability in emergence. Crop Science, v.44, n.3, p.847-854, 2004b. https://dl.sciencesocieties.org/publications/cs/ abstracts/44/3/847

MELO, P.C.S.; ANUNCIAÇÃO FILHO, C.J.; OLIVEIRA, F.J.; BASTOS, G.Q.; TABOSA, J.N.; SANTOS, V.F.; MELO, M.R.C.S. Selection of genotypes of salinity tolerant rice during the vegetative phase. Ciencia Rural, v.36, n.1, p.58-64, 2006. http://www.scielo.br/pdf/cr/v36n1/a09v36n1.pdf

MEROTTO-JÚNIOR, A.; SANGOI, L.; ENDER, M.; GUIDOLIN, A.F.; HAVERROTH, H.S. Uneven emergence reduces maize grain yield. Ciência Rural, v.29, n.4, p.595-601, 1999. http://www.scielo.br/pdf/cr/v29n4/ a04v29n4.pdf 
MIELERZSKI, F.; SCHUCH, L.O.B.; PESKE, S.T.; PANOZZO, L.E.; PESKE, F.B.; CARVALHO, R.R. Field performance of isolated plants of hybrid rice in function of the seed physiological quality. Journal of Seed Science, v.30, n.3, p.86-94, 2008. http://www.scielo.br/pdf/rbs/v30n3/18.pdf

MONDO, V.H.V.; CICERO, S.M.; DOURADO-NETO, D.; PUPIM, T.L; DIAS, M.A.N. Maize seed vigor and plant performance. Journal of Seed Science, v.34, n.1, p.143-155, 2012. http://www.scielo.br/scielo. php?script=sci_arttext\&pid=S0101-31222012000100018

MONDO, V.H.V.; CICERO, S.M.; DOURADO-NETO, D.; PUPIM, T.L; DIAS, M.A.N. Effect of seed vigor on intraspecific competition and grain yield in maize. Agronomy Journal, v.105, n.1, p.222-228, 2013a. https:// dl.sciencesocieties.org/publications/aj/abstracts/105/1/222

MONDO, V.H.V.; CICERO, S.M.; DOURADO-NETO, D.; PUPIM, T.L; DIAS, M.A.N. Seed vigor and initial growth of maize crop. Journal of Seed Science, v.35, n.1, p.64-69, 2013b. http://www.scielo.br/scielo. php?script $=$ sci arttext\&pid=S2317-15372013000100009

MONDO, V.H.V.; DIAS, M.A.N.; CICERO, S.M. Maize seed vigor and its effects on crop cultivation cycle. Revista de Agricultura, v.90, n.2, p.168-178, 2015. http://www.fealq.org.br/ojs/index.php/ revistadeagricultura/article/view/178

POMMEL, B.; MOURAUX, D.; CAPPELLEN, O.; LEDENT, J.F. Influence of delayed emergence and canopy skips on the growth and development of maize plants: a plant scale approach with CERES-Maize. European Journal of Agronomy, v.16, p.263-277, 2002. http://www.sciencedirect.com/science/ article/pii/S1161030101001307
SCHUCH, L.O.B.; NEDEL, J.L.; ASSIS, F.N.; MAIA, M.S. Seed vigor and growth analysis of black oats. Scientia Agricola, v.57, n.2, p.305-312, 2000. http://www.scielo.br/scielo.php?pid=S0103$90162000000200018 \&$ script $=$ sci $\operatorname{arttext}$

SCHUCH ， L.O.B.; KOLCHINSKI, E.M.; FINATTO, J.A. Seed physiological quality and individual plants performance in soybean. Journal of Seed Science, v.31, n.1, p.144-149, 2009. http://www.scielo.br/pdf/rbs/ v31n1/a16v31n1.pdf

SANTOS, A.B.; STONE, L.F.; VIEIRA, N.R.A. A cultura do arroz no Brasil. $2^{\mathrm{a}}$. Ed. Santo Antônio de Goiás, GO. Embrapa Arroz e Feijão. 2006. 1000p.

SILVA, S.C.; HEINEMANN, A.B.; PAZ, R.L.F.; AMORIM, A.O Informações meteorológicas para pesquisa e planejamento agrícola, referentes ao ano de 2009, do município de Santo Antônio de Goiás, GO. Santo Antônio de Goiás, Embrapa Arroz e Feijão. (EMBRAPA, CNPAF Documentos, 256). 2010. 32p. http://www.cnpaf.embrapa.br/publicacoes/ index.php/documentos/article/view/Doc.\%20298

TOLLENAAR, M.; DEEN, W.; ECHARTE, L.; LIU, W. Effect of crowding stress on dry matter accumulation and harvest index. Agronomy Journal, v.98, n.4, p.930-937, 2006. https://dl.sciencesocieties.org/publications/aj/ abstracts/98/4/930

VANZOLINI, S.; CARVALHO, N.M. Effects of soybean seed vigor on field plant performance. Journal of Seed Science, v.24, n.1, p.33-41, 2002. http:// www.scielo.br/pdf/rbs/v24n1/v24n1a06.pdf 